九州大学学術情報リポジトリ

Kyushu University Institutional Repository

\title{
A New Approach to Pectin Manufacture by Copper Method : Part 2. Preparation of Dry Metal- Pect in Complex
}

Kausar, Pervez

Food Processing Laboratory, Faculty of Agriculture, Kyushu University

Nomura, Danj $\mathrm{i}$

Food Processing Laboratory, Faculty of Agriculture, Kyushu University

https://doi.org/10.5109/23733

出版情報: 九州大学大学院農学研究院紀要. 26 (1)，pp.1-7，1981-10. Kyushu University バージョン：

権利関係 : 
J. Fac. Agr., Kyushu Univ., 26(1), 1-7 (1981)

\title{
A New Approach to Pectin Manufacture by Copper Method
}

\section{Part 2. Preparation of Dry Metal-Pectin Complex}

\section{Pervez Kausar and Danji Nomura}

\author{
Food Processing Laboratory, Faculty of Agriculture,
} Kyushu University 46-09, Fukuoka 812

(Received March 7. 1981)

\begin{abstract}
This study was part of an attempt to develop a disintegrated pectin manufacture process to utilize to its maximum already existing facilities at citrus juice plants as well as to cut down the energy and transport costs by maximum using the wet leached peel and transporting dry metal-pectin complex to a central pectin manufacture plant for further processing instead of transporting huge volume of pectin pomace. This type of approach was thought essential to prepare cost wise competiable pectin from Unshu citrus peel which have extremely short harvest season and the pectin content of peel is also very low. Low ash metal-pectin precipitates having 8-10\% T.S.S. were most suitable for preparing partially demetaled dry complex of good solubility. Partially demetaled dry metal-pectin complexes were prepared by using copper, copper + aluminum and aluminum. Dry complex prepared by using $1: \mathbf{1}$ copper + aluminum proved most economical as quantity of alcohol and acid required were 14 liters and 0.67 liters as compared to 46 liters and 25.528.0 liters of alcohol and 0.8 liters and 1.86-2.05 liters of acid in case of copper and aluminum methods, respectively. for every 15 liters of $0.50-0.55 \%$ pectin extract. It was further noted that washing with acidified alcohol and simultaneous pressing helped to eliminate metal ions more efficiently as compared to simple washing without pressing. Proper shreding after every press was essential to get good results. Complex prepared by combination of copper + aluminum gave higher yield as compared to complexes prepared by using copper or aluminum methods.
\end{abstract}

\section{INTRODUCTION}

Pectin production from Unshu citrus peel (the main citrus variety grown in Japan) depends upon the development of a more economical and flexible process which can compete cost wise with the existing pectin manufacturing processes 1.e., alcohol process and aluminum process. Moreover, this process must also have the flexibility to match with the typical Unshu citrus harvesting pattern and qualitative characteristics. Commercially pectin pomaces used for pectin manufacture contain much higher pectin (53.3 and $42.6 \% 150$ grade pectin in case of lime and lemon commercially leached and dried pomaces as reported by Crandall et al., 1978) as compared to only $23 \%$ in case of Unshu leached pomace as reported by Kausar and Nomura (1980).

Citrus harvest season in Japan is extremely short (only three months), whereas, suitability of citrus peel for manufacturing pectin pomace is still 
more limited to a time span of only two months (from Nov. to the end of Dec.). Large scale production of low pectin content pomace and then its transport to an independent pectin manufacture plant is one of the important limiting factor which will make the cost of pectin manufactured thereby more expensive as compared to the imported pectin.

Keeping in view these factors this study was undertaken to develop a disintegrated and simple process by which dried metal-pectin complex can be prepared in the juice factories using to the maximum the wet leached peel to make dry metal-pectin complex using the already existing facilities at the juice plants. This will help to cut down the transport and energy costs involved for the production of huge volume of low pectin pomace.

Dry metal-pectin complexes of good solubility will be prepared by using copper, copper + aluminum and aluminum and compared on the basis of economy in terms of acid and alcohol used for the partial purification and deashing.

Concentration of pectin by using aluminum salt has been reported by Wilson (1925) and Joseph and Havighorst (1952), whereas, concentration by using copper salt was reported by Nomura and Naito $(1953,1955)$.

This study was undertaken to create the possibility of preparing dry metal-pectin complex of good solubility at different juice plants and latter this complex may be pooled together in a central pectin manufacture plant to produce modified pectins out of it.

Manufacture of pectin from dry metal-pectin complex by using IER (ion exchange resin) will be presented in the next paper.

\section{MATERIALS AND METHODS}

Raw meterial: Unshu citrus peel was obtained from Fukuoka-ken Engeiren Amagi Mikan Juice Factory during 1978-79 at the optimum harvest season (Nov. 15-Jan. 15) and was cold leached, dried to 7-10 \%6 moisture in a forced draft air oven at $90^{\circ} \mathrm{C}$ according to the procedure described in the previous paper (Kausar and Nomura, 1980).

Pectin extraction: Pectin was extracted from the pomace with 40 times by weight of acidified water $(0.13 \% \mathrm{HCI})$ for 45 minutes at $95^{\circ} \mathrm{C}$ and filtered through a coarse cotton cloth bag.

Making dry metal-pectin complex : Dry metal-pectin complexes were prepared according to the schemes presented in Figs. 1, 2 and 3. Pressing of the precipitates was done in a manually operated screw type press.

Analyses: Moisture, T.S.S. (total soluble solids) and ash contents were measured according to AOAC (1960) methods. Copper contents were measured by colorimetric method using 2, 2'-Biquinoline as described by Sandell (1959).

\section{RESULTS}

Conditions for precipitation, purification and partial deashing of metalpectin complexes are presented in Figs. 1, 2 and 3. Results showed that cop- 
per combines with pectin at $\mathrm{pH} 2.8$ whereas, aluminum at $\mathrm{pH} 4.0$ when judged on the basis of appearance of precipitates in series of experiments. When the mixture of copper + aluminum was used for precipitation, pectin extract should be adjusted to $\mathrm{pH} 2.8$ and then mixture of metal salts (copper and aluminum) should be added and mixed to give full chance to $\mathrm{Cu}^{2+}$ ions to combine with pectin molecules and then $\mathrm{pH}$ should be raised to 4.0 to allow $\mathrm{Al}^{3+}$ ion to occupy the remaining free active sites at copper pectin complex.

First washing of metal-pectin complexes with acidified alcohol according to the schemes were selected on the basis of amount of acid and alcohol required for partial demineralization after series of experimentation and represent the most suitable combinations in all the cases. It was further noted that simultaneous pressing after washing with acidified alcohol to raise the T.S.S. to $9-10,18-20$ and 14-16\% in case of copper, copper + aluminum and aluminum methods respectively, was essential to get rid of most of the metal ions and other impurities. Shreding of the precipitates after every press in all the cases was essential for proper penetration of alcohol and acid and diffusing out of salts. Second washing in case of copper or aluminum methods (Figs. 1 and 3) required further addition of acid, hence a third washing was essential for neutralization, whereas, when combination of copper + aluminum (Fig. 2) was used for precipitation second alcohol washing and neutralization produced the required quality complex.

Results presented in Table 1 showed that when copper was used for precipitation the volume of ppt./15 liters of 0.50-0. $55 \%$ pectin extract was very large $(2.2-2.3 \mathrm{~kg})$ and the T.S.S. were raised to only 4.0-4.2\%. More-

1 Clarified extract $(0.50-0.55 \%$ pectin $)+25 \mathrm{mg} \mathrm{Cu}^{2+} / 100 \mathrm{ml}$ of extract.

2 - Agitated mixing, $\mathrm{pH}$ adjusted to 2.8 with conc. $\mathrm{NH}_{4} \mathrm{OH}$ and allowed to stand for $30 \mathrm{~min}$.

3 - Drained and centrifuged (T.S.S. 4.0-4.2 \%6)

4- One $\mathrm{kg}$ of ppt. mixed with $10 \mathrm{ml}$ of conc. HCI until viscous sol. (10-15 min.).

5 - Reprecipitated by adding 0.75 liters of $95 \%$ alcohol and mixed for one hour, centrifuged and pressed (T.S.S. 9-10\%).

\section{1}

6 - Second washing with 0.75 liters of $85 \%$ alcohol (containing $15 \mathrm{ml}$ of conc. $\mathrm{HCl}$ ) and mixed for one hour.

7 - Drained and pressed (T.S.S. 18-20\%).

8 - Precipitate shreded and mixed with 0.75 liters of $95 \%$ alcohol for one hour and neutralized with conc. $\mathrm{NH}_{4} \mathrm{OH}(\mathrm{pH}$ 4.0). drained and pressed (T.S.S. 28-32 \%).

(Alcohol recovered was reused for the first washing of next batch)

9 - Precipitate dried and grinded to pass through 80 mesh screen.

Fig. 1. Scheme for the preparation of dry $\mathrm{Cu}$-pectin complex. 
1 - Clarified extract $(0.50-0.55 \%$ pectin), $\mathrm{pH}$ adjusted to 2.8 with conc. $\mathrm{NH}, \mathrm{OH}+$ $30 \mathrm{mg}(1: 1) \mathrm{Cu}^{2+}+\mathrm{Al}^{3+} / 100 \mathrm{ml}$ pectin extract.

2 - Agitated mixing, $\mathrm{pH}$ adjusted to 4.0 with conc. $\mathrm{NH}_{4} \mathrm{OH}$, allowed to stand for few min and drained on a 100 mesh nylon screen net and pressed (T.S.S. 8-10 g).

3 - One $\mathrm{kg}$ of ppt. mixed with 1.5 liters of $70 \%$ alcohol (containing $50 \mathrm{ml}$ of conc. $\mathrm{HCI}$ ) for one hour.

4 - Drained and pressed (T.S.S. 18-20\%).

5 - Precipitate shreded, mixed for one hour with $85 \%$ alcohol and then neutralized with conc. $\mathrm{NH}_{4} \mathrm{OH}(\mathrm{pH} 4.0)$.

6 - Drained and pressed (T.S.S. 28-32 \%).

(Alcohol recovered was reused for the first washing of next batch)

7 - Precipitate dried and grinded to pass through 80 mesh screen.

Fig. 2. Scheme for the preparation of dry $\mathrm{Cu}$. Al-pectin complex.

1- Clarified extract (0.50-o. $55 \%$ pectin $)+50-75 \mathrm{mg}$ of $\mathrm{Al}^{3+} / 100 \mathrm{ml}$ of extract.

2 - Agitated mixing, $\mathrm{pH}$ adjusted to 4.0 and allowed to stand for few min.

3 - Drained on a 100 mesh screen and pressed (T.S.S. 8.5-12.0\%).

4 - One $\mathrm{kg}$ of ppt. shreded and mixed with 2 liters of $65 \%$ ethanol (containing $100 \mathrm{ml}$ of conc. $\mathrm{HCl}$ ) for one hour drained and pressed (T.S.S. 14-16 \%).

5 - Precipitate shreded and mixed with 'one liters of $75 \%$ ethanol (containing $50 \mathrm{ml}$ of conc. $\mathrm{HCl}$ ) for one hour.

6 - Drained and pressed (T.S.S. 26-32 \%).

7 - Precipitate shreded, mixed with one liter of $95 \%$ ethanol for one hour, and then neutralized with conc. $\mathrm{NH}_{4} \mathrm{OH}(\mathrm{pH} 4.0)$. drained and pressed.

(Alcohol recovered was reused for the first washing of next batch)

8 - Precipitate dried and grinded to pass through 80 mesh screen.

Fig. 3. Scheme for the preparation of dry Al-pectin complex.

over, centrifugation was required to separate the copper-pectin complex. Mixture of $(1: 1)$ copper + aluminum $30 \mathrm{mg}$ or $50 \mathrm{mg}$ of aluminum/ $100 \mathrm{ml}$ of 0.50 $0.55 \%$ pectin extract produced almost the same quantity of precipitate when pressed under similar conditions, whereas, the ash content was much higher in case of aluminum precipitation. Results further revealed that when only copper or copper + aluminum were used to make complex with pectin, 37-53 \% of total copper added was washed out in the drain. Amount of acid and alcohol required for purification and partial deashing and the ash contents of 


\section{Pectin Manufacture}

Table 1. Quantity and analysis of different types of precipitates. Results reported are average of at least five batches.

\begin{tabular}{|c|c|c|c|c|c|c|}
\hline \multirow[b]{2}{*}{$\begin{array}{l}\text { Volume } \\
\text { of pectin } \\
\text { extract }\end{array}$} & \multirow[b]{2}{*}{$\begin{array}{l}\text { Amount of } \\
\text { precipitant } \\
\text { used }\end{array}$} & \multirow[b]{2}{*}{$\begin{array}{l}\text { Precipitate } \\
\text { separation } \\
\text { method }\end{array}$} & Drain & \multicolumn{3}{|c|}{ Precipitate } \\
\hline & & & $\begin{array}{l}\text { Percentage } \\
\text { of total } \\
\text { copper } \\
\text { added }\end{array}$ & $\begin{array}{l}\text { Total } \\
\text { weight } \\
\text { (kg) }\end{array}$ & $\begin{array}{l}\text { Total } \\
\text { soluble } \\
\text { solid } \\
(\%)\end{array}$ & $\begin{array}{c}\text { Ash } \\
\text { content } \\
(\%)\end{array}$ \\
\hline \multirow{6}{*}{$\begin{array}{l}150^{1 \text { iters }} \\
0.55 . \% \% \\
\text { pectin } \\
\text { extract }\end{array}$} & $\begin{array}{l}20 \mathrm{mg} \text { of } \mathrm{Cu}^{2+} \text { / } \\
100 \mathrm{ml} \text { extract } \\
\text { (total } 3.00 \mathrm{~g} \text { ) }\end{array}$ & $\begin{array}{l}\text { Centrifuging* } \\
\text { the whole } \\
\text { batch }\end{array}$ & $53 \%$ & $2.3-2.5$ & $3.8-4.0$ & $4.7-4.9$ \\
\hline & $\begin{array}{l}25 \mathrm{mg} \text { of } \mathrm{Cu}^{2+} / \\
100 \mathrm{ml} \text { extract } \\
\text { (total } 3.75 \mathrm{~g} \text { ) }\end{array}$ & $\begin{array}{l}\text { Drainipg } \\
\text { centrifugatoh }\end{array}$ & $50 \%$ & $2.2-2.3$ & 4. o- 4.2 & $4.9-5.2$ \\
\hline & 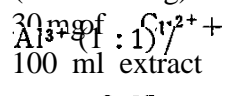 & $\begin{array}{l}\text { Draining } \\
\text { and }\end{array}$ & $37-40 \%$ & $0.9-1.1$ & $8.0-10.0$ & $5.3-5.6$ \\
\hline & $\begin{array}{l}(\text { total } 2.25+ \\
2.25 \mathrm{~g})\end{array}$ & pressing & & & & \\
\hline & $\begin{array}{l}50 \mathrm{mg} \text { of } \mathrm{Al}^{3+} / \\
100 \mathrm{ml} \text { extract } \\
\text { (total } 7.50 \mathrm{~g} \text { ) }\end{array}$ & - do- & - & $0.9-\mathrm{L} 0$ & $8.5-9.5$ & 8.5 \\
\hline & $\begin{array}{l}75 \mathrm{mg} \text { of } \mathrm{Al}^{3+} / \\
100 \mathrm{ml} \text { extract } \\
\text { (total } 11.25 \mathrm{~g} \text { ) }\end{array}$ & - do- & - & $0.8-0.9$ & $11.5-12.0$ & 13.4 \\
\hline
\end{tabular}

* Centrifugation was done at $5,000 \mathrm{~g}$ for $5 \mathrm{~min}$.

Table 2. Quantity of acid and alcohol required for preparation of one $\mathrm{kg}$ of dried metal-pectin complex. Results reported are average of at least five batches.

\begin{tabular}{|c|c|c|c|c|c|c|c|}
\hline \multicolumn{3}{|c|}{ Type of precipitates } & \multirow{2}{*}{$\begin{array}{l}\text { Weight } \\
\text { of wet } \\
\text { precipi- } \\
\text { ) tate }(\mathrm{kg}\end{array}$} & \multirow{2}{*}{$\begin{array}{l}\text { Amount } \\
\text { of } \\
\text { alcohol } \\
\text { g) used (L) }\end{array}$} & \multirow{2}{*}{$\begin{array}{l}\text { Amount } \\
\text { of acid } \\
\text { used } \\
\text { (L) }\end{array}$} & \multirow{2}{*}{$\begin{array}{l}\text { Final } \\
\text { ash } \\
\text { content } \\
(\%)\end{array}$} & \multirow{2}{*}{ Solubility } \\
\hline Precipitant used & $\begin{array}{c}\text { T.S.S. } \\
(\mathscr{\sigma})\end{array}$ & $\underset{(\%}{\text { Ash }}$ & & & & & \\
\hline 25 pectmg of Curact $100 \mathrm{ml}$ & $4.0-4.2$ & $4.9-5.2$ & 32.5 & 46.0 & 0.81 & $0.6-0.8$ & good* \\
\hline $\begin{array}{l}30 \mathrm{mg} \text { of } \mathrm{Cu}^{2+}+\mathrm{Al}^{3+} \\
(1: \mathrm{I}) / 100 \mathrm{ml} \text { pectin } \\
\text { extract }\end{array}$ & $8.0-10.0$ & 5. 3-5.6 & $13.0-14.0$ & 14.0 & 0.67 & $0.6-1.0$ & good \\
\hline 5ectmg of $\mathrm{Atract}^{3+} / 100 \mathrm{ml}$ & 9.0 & 8.5 & 13.7 & 14.0 & 0.67 & $2.5-3.2$ & poor** \\
\hline$-\mathrm{do}-$ & 9.0 & 8.5 & 13.7 & 25.5 & 1.86 & $0.6-0.8$ & good \\
\hline pemg of $\mathrm{Al}^{3+}+100 \mathrm{ml}$ & 12.0 & 13.4 & 12.4 & 28.0 & 2.05 & $0.6-0.8$ & good \\
\hline
\end{tabular}

* Good solubility-represents no settling appeared in $1 \%$ metal-pectin complex solution on overnight stay in test tube.

** Poor solubility-represents settling appeared in $1 \%$ metal-pectin complex solution on overnight stay in test tube.

final products are presented in Table 2. Results revealed that 46, 14 and 25.528.0 liters of alcohol and 0.81, 0.67 and 1.86-2.05 liters of acid were required in case of copper, copper + aluminum and aluminum methods respectively, to produce one $\mathrm{kg}$ of dry metal-pectin complex of good solubility. It was further 
Table 3. Yield and ash contents of dried metal-pectin complexes. Average of at least five batches each.

\begin{tabular}{|c|c|c|c|c|}
\hline $\begin{array}{c}\text { Volume of pectin } \\
\text { extract }\end{array}$ & $\begin{array}{l}\text { Amount of } \\
\text { precipitant used }\end{array}$ & Yield (g) & Total ash (\%) & $\begin{array}{c}\text { Total } \mathrm{Cu}^{2+} \\
(\%)\end{array}$ \\
\hline \multirow{4}{*}{$\begin{array}{l}15 \text { liters of } 0.50-\text { o. } 55 \\
\% \text { pectin extract }\end{array}$} & $\begin{array}{l}25 \mathrm{mg} \text { of } \mathrm{Cu}^{2+} / 100 \mathrm{ml} \\
\text { extract }\end{array}$ & 70 & 0.6-O. 8 & 0.41 \\
\hline & $\begin{array}{l}30 \mathrm{mg} \text { of } \mathrm{Cu}^{2+}+\mathrm{Al}^{3+} \\
\left(1: \frac{1}{1}\right) / 100 \mathrm{ml} \text { extract }\end{array}$ & 75 & 0. 6-1. 0 & \multirow[t]{3}{*}{0.11} \\
\hline & $\begin{array}{l}50 \mathrm{mg} \text { of } \mathrm{Al}^{3+} / \\
100 \mathrm{ml} \text { extract }\end{array}$ & 70 & $0.6-0 . a$ & \\
\hline & $\begin{array}{l}75 \mathrm{mg} \text { of } \mathrm{Al}^{3+} / \\
100 \mathrm{ml} \mathrm{extract}\end{array}$ & 70 & 0.6-O. 8 & \\
\hline
\end{tabular}

noted that when $50 \mathrm{mg}$ of $\mathrm{Al}^{3+} / 100 \mathrm{ml}$ of pectin extract was used for precipitation and washed under similar conditions as in case of copper + aluminum method, the ash content of final product was much higher and it also showed poor solubility.

Yield of dry metal-pectin complexes and the copper content of final products are presented in Table 3. Results showed that yield of the dry complexes was identical $(70 \mathrm{~g})$ when copper or aluminum was used to precipitate pectin from 15 liters of $0.50-0.55 \%$ pectin extract, whereas, it increased to 75 $\mathrm{g}$ when copper + aluminum was used. Copper content of dry complexes prepared by copper and aluminum methods contained $0.41 \%$ and $0.11 \%$ of copper respectively, in the final products.

\section{DISCUSSION}

Concentration of pectin by using $\mathrm{Cu}^{2+}$ ions required centrifugation to separate copper-pectin complex. However, T.S.S. were still not high enough, therefore, the volume of acidified alcohol required to prepare dry complex was much higher as compared to copper + aluminum and aluminum methods. It was further noted that washing out of copper from pectin complex was more easier as compared to aluminum. This conclusion was based on the amount of acid required for washing out metal ions and the amount of copper left in the dry complex prepared by copper + aluminum method.

Yield of dry metal-pectin complex was identical in case of copper and aluminum methods. Nomura and Naito (1953) reported identical yields of pectin when alcohol and copper methods were compared. In this study it was noted that yield of dry metal-pectin complex increased from 70 to $75 \mathrm{~g}$ when copper + aluminum was used for precipitation as compared to copper or aluminum methods. This observation reflects very complex nature of pectin molecule and seems colloidal precitation and chemical precipitation of pectin molecule and metal ions proceed side by side and that copper ions are more responsible for colloidal precipitation, whereas, some of the aluminum ions enter into chemical combination after copper had brought together all the negatively charged particles in the pectin extract, forming a net work and precipitating 
out all types of pectins. This might has resulted in the higher yield of dry complex.

Results revealed that demetaling of metal-pectin complex could be achieved quickly and economically by first changing pectin into hydrogen form with acid in the presence of alcohol and then removing the maximum amount of solvent and water by pressing, as compared to simple washing with highly acidified alcohol without pressing, which will require many more washings to prepare dry metal-pectin complex of good solubility. It was further noted that metal-pectin precipitates having about 8-10 $\%$ T.S.S. were more suitable for making dry complex of good solubility due to the possibility of washing out maximum metal ions during the first press. Complex having too high T.S.S. (more than 12\%) and ash contents required comparatively dilute alcohol and high acid to get better penetration of alcohol and acid in the complex, but using of too dilute alcohol to get better penetration resulted in inefficient pressing which could not remove enough metal ions from the complex. Proper shreding of the precipitate after every press was extremely important.

Combination $(1: 1)$ copper + aluminum used to make dry metal-pectin complex gave the best results when compared on the basis of yield and economy.

\section{REFERENCES}

AOAC 1960 Methods of Analysis. 9th ed. Assoc. Official Anal. Chem., Washington D.C. Crandall, P. G., R. J. Braddock and A. H. Rouse 1978 Effect of drying on pectin made from lime and lemon pomace. J. Food Sci., 43: 1680-1682

Joseph, G. H. and C. R. Havighorst 1952 Engineering quality pectins. Food Eng., 24(11): 87-89, 160-162

Kausar, P. and D. Nomura 1980 A new approach to pectin manufacture by copper method. Part 1. Preparation of pectin pomace. pectin extraction and concentration by copper salt. J. Fac. Agr., Kyushu Univ., 25(2.3): 61-71

Nomura. D. and N. Naito 1953 Fundamental studies on the manufacture of Natsudaidai juice. Part 8 . On the utilization of the residue (byproducts) in process of manufacturing orange juice. No. 1. Pectin manufacture by using IER. J. Fermentation Techn., 31: 275-279 (in Japanese)

Nomura. D. and N. Naito 1955 Fundamental studies on the manufacture of Natsudaidai juice. Part 15. On the utilization of the residue (byproducts) in process of manufacturing orange juice (2). Decopperation of pectin copper salt by cataphoresis. $J$. Nippon Nogeikagaku Kaishi, 29: 412-415 (in Japanese)

Sandell, E. B. 1959 Colorimetric Determination of Traces of Metals, Vol. 3. 3rd ed. Revised by E. B. Sandell, Interscience Publishers, Inc., New York, pp. 451-453

Wilson, C. P. 1925 The manufacture of pectin. Ind. Eng. Chem., 17: 1065-1067 